Tung, H. T. (2017). Adjustment of interbank lending in pre- and post-regulation periods: Empirical analysis of Vietnamese commercial banks. Journal of

International Studies, 10(3), 64-76. doi:10.14254/2071-8330.2017/10-3/5

\title{
Adjustment of interbank lending in pre- and post-regulation periods: Empirical analysis of Vietnamese commercial banks
}

\author{
Ho Thanh Tung \\ Faculty of Management and Economics, \\ Tomas Bata University in Zlin, Crech Republic; \\ Faculty of Finance and Banking, \\ Ton Duc Thang University, Hochiminh city, Vietnam \\ Email: bothanbtung@tdt.edu.vn
}

\begin{abstract}
This article aims to analyze the interbank lending adjustment during the period when Vietnamese commercial banks are compliant with some parts of the Basel regulation framework. A pilot regulation period has started in 2011 and full application will be effective by the end of 2018. Partial adjustment models and variance decomposition are used for the analyses. In the analysis of the quarterly released financial statements of Vietnamese commercial banks in the period from 2008/Q1 to 2015/Q4, the empirical evidence showed that throughout the period, lending to non-bank and high liquidity assets contributed to the adjustment in both long run and short run with a negative association. In addition, the loan loss allowance contributed to the adjustment in the post-regulation period only with a positive association. These highly contributing factors also show a potential shock after the adjustment of the interbank lending. The results imply there is a need for interbank lending portfolio report and an efficient control over the IRB of Vietnamese commercial banks.
\end{abstract}

Keywords: bank regulation, capital regulation, Basel regulation, interbank lending, adjustment speed, Vietnamese commercial banks.

JEL Classification: D24, E51, G21, G28

\section{INTRODUCTION}

This study examines the interbank lending adjustment of Vietnamese commercial banks together with the pilot study recently conducted to apply the Basel framework in the Vietnamese commercial bank sector, and the application has been implemented since the beginning of 2011. It is important to measure the speed of Vietnamese commercial banks' interbank capital adjustment while adopting this regulation requirement.

Recently, Craig et al. (2015) stated that information from the interbank market was used to assess the costs of a systemic bank failure. The interbank market is a supply channel that provides liquidity for shortrun liquidity demand of banks. Heider et al. (2015) identified that the interbank market provide benchmark rates for the pricing of fixed-income securities throughout the economy and are essential to banks' liquidity management. Additionally, Garcia-de-Andoain et al. (2016) stated that when the ECB "took over" the 
liquidity provision role at the interbank market, it made the interbank market become under severe stress. These findings implied that the change at the interbank market was connected to the systemic risks.

Vietnam is a developing country, where the economic integration is still under progress. Prior to 2000, all Vietnamese banks belonged to the government. At present, 36 out of 37 banks in Vietnam are jointstock commercial banks. The most important evolution for Vietnamese commercial banks are the Laws for Vietnamese credit institutions issued in 2010. Accordingly, the Basel regulation requirement is under the process of adoption. In the official letter number 1601/2014-NHNN/TTGSNH as of March, 17, 2014 issued by the State Bank of Vietnam, the governor expressed that the State Bank of Vietnam intended to apply the full Basel regulation requirement to all Vietnamese commercial banks in 2018. The process is a good opportunity for an empirical analysis to study economic integration on the case of a country, where the Basel regulatory implementation is at the starting stage. Whereby, some findings of this article suggest there is a need for more disclosure and supervision of the interbank capital, since the opposite could lead to a systemic potential contagion via the interbank capital.

This article uses partial adjustment models to examine the effect of relevant factors on the adjustment speed of interbank capital of Vietnamese commercial banks. Since 2011, Vietnamese commercial banks have applied some regulation requirements of the Basel framework, so the adjustment analysis also gave some evidence of differences in the adjustment between the pre- and post-regulation periods. Then, according to the contribution to the adjustment of factors, the author uses the variance decomposition analysis as a combination technique to detect the potential shock that might occur in the interbank contagion in the period from 2008/Q1 to 2015/Q4. There is evidence of shocks from the liquidity and the activation of a contagion mechanism from the loan loss allowance that followed the adjustment of the interbank lending. The study also contributes to the empirical analysis of the interbank lending by giving some relevant evidence in order to deepen banking regulation and to make Vietnamese commercial banking system more sound, transparent and prepared for further economic development. Other countries which would like to learn more on the experience of launching the Basel regulatory framework may find our results useful.

\section{LITERATURE REVIEW}

The economics literature used for this article focuses on the interbank capital contagion, an aspect of systemic contagion of bank risk. The methodologies used are the features of partial adjustment models and the variance decomposition analysis.

Affinito (2012) analysed Italian bank-by-bank data of each interbank borrower and lender to assess the relationship between banks in the interbank market. The results showed that in Italy, the interbank customer relationships were stable and strong between pairs of borrowing and lending banks, persisted over time, and functioned well during the crisis, enabling the healthier banks to provide funds and the troubled ones to receive funds. Except for the rating information that used for the model fit, Affinito computed a large number of variables which were calculated almost on the value of transactions, assets or liabilities. However, the results pointed out are only relationships between banks in the interbank market and are missing the vision to show whether there is potential contagion in the interbank market change.

Tian et al. (2013) developed a theoretical framework that could identify a range of factors that strengthen or weaken the possibility of contagion and bailout. The choices available for so-called healthy bank included interbank capital. An important aspect was the amount of capital it held and the size of its exposure to the joint project. Contagion would occur if the bank's capital holding was below the smaller amount of regulatory capital required to take over or liquidate its project. Tian et al. (2013) also concluded that increasing the minimum regulatory capital did not necessarily reduce contagion, while the precautionary 
risk management inventory buffer of banks could help the bank to avoid contagion. In my article, the empirical analysis of the pre- and post-regulation periods is a confirmation of these conclusions in the case of Vietnam. Moreover, the forecast in my article is the result of the consolidation from both the theory and the confirmation.

Georg (2013) proposed a dynamic multi-agent model of a banking system with the central bank. Banks optimize a portfolio of risky investments and riskless excess reserve according to their risk, return, and liquidity preferences. They were linked via interbank loans and face a stochastic deposit supply. Comparing different interbank network structures, it is shown that money-center networks were more stable than random networks. The evidence showed that the central bank stabilized interbank markets in the short run only. Systemic risk via contagion was compared with common shocks, and it was shown that both forms of systemic risk require different optimal policy responses. In the same line with Georg, in 't Veld \& van Lelyveld (2014) clarified an apparent confusion between the core periphery (CP) and nested split graph (NSG) models, and found a better fit of the CP model in terms of the error. These combination methods fitted networks on the Dutch data and made clear that the core periphery model offered a better fit to the interbank market. This study recognized a hierarchical structure issued for the interbank market where the core lending banks reserve the buffers were lower than the other ones. The findings of in 't Veld \& van Lelyveld (2014) highlight that the core banks faced more systemically shocks than the other ones. The authors also suggested doing further research for the purpose of systemic risk assessments of the interbank market behaviour to provide further guidelines for supervisory authorities. Besides the findings, in 't Veld \& van Lelyveld (2014) suggested more research on the additional of the relevant buffer factors and systemic shock to have better empirical evidence.

In order to add an empirical study to the literature focused on developed countries mostly, Distinguin et al. (2013b) analyzed an empirical disciplining role of interbank deposits of Eastern European countries where "stock markets and bond markets are relatively narrow and less liquid than in western countries" (see Distinguin et al ., 2013a). The authors found out that the market discipline had been effective in Central and Eastern Europe since the implementation of explicit deposit insurance. However, state-owned banks had not been disciplined probably because they could benefit from the implicit insurance. Based on several factors affecting the strength of the discipline, the authors argued that a stronger regulatory discipline could reduce the risk of the interbank market. In addition to the empirical analyses, Temizsoy et al. (2015) used a number of transactions, such as interbank rate spread and trading volume to analyse the structure of links between financial institutions participating in the e-MID (the only transparent electronic platform in Europe and the USA), an interbank market. The success of Temizsoy et al. (2015) that both lender preference index (LPI) and borrower preference index (BPI) could reflect the relationship of a pair bank in the interbank market was evident. The authors suggested that the LPI and BPI indicators should be monitored together with the trade volume in the interbank markets as the indicators for the early warning of a financial turmoil. The reminding from the conclusion of these empirical analyses, there is a need for further examination to point out which related indicator of the interbank capital should be followed, especially in the case of developing countries and where the Basel framework is applied.

Fink et al. (2016) proposed an algorithm to model contagion in the interbank market via the credit quality channel, in which shocks were transmitted via asset devaluations and deteriorations in the credit quality. The authors developed models which could simulate the loss and the contagion of the interbank market in some scenarios, in which the expected losses from an increased probability of default and a new metric termed the banking system loss. This enabled to estimate the potential regulatory capital loss to the banking system due to contagion via interbank lending. Fink et al. (2016) argued that their algorithm could 
be useful by using the information of probability of default for the contagion simulation, instrument calibration and policy evaluation.

The aim of my article is to distinguish whether the $\mathrm{VcB}$ faces the interbank contagion risk along with their implementation of the SBV's regulation requirement. The research is conducted through the analysis of interbank lending adjustment. This is an empirical study, a similar type to Affinito (2012), Distinguin et al. (2013a), in 't Veld \& van Lelyveld (2014), Temizsoy et al. (2015) and Fink et al. (2016). My study analyzes the interbank lending, and provides the empirical evidence of the interbank lending adjustment estimation and variance decomposition analysis. My article could imply some potential contagions that are related to the interbank lending in the case of Vietnamese commercial banks. The empirical evidence of the article could contribute to the interbank capital research.

Recently, partial adjustment models have been significantly used for empirical analysis studies the capital structure and its adjustment. As in (Ly et al., 2017) to investigate the effect of Net Stable Funding Ratio adjustment speed on the systemic; Shimizu (2015) to analyze the adjustment of denominators capital ratio in Japanese banks; (Cook \& Tang, 2010) to estimate the impact of macroeconomic factors on the speed of capital structure adjustment. My paper is a new study of the interbank market which could be added to the studies that deal with the empirical analysis by using partial adjustment models, and it is the first study of this topic to use the partial adjustment models in Vietnam. Additionally, Fink et al. (2016) proved that the change of loan loss allowance in the past could influence a contagion process. Based on the mechanism ideas of Fink et al. (2016), my article uses the variance decomposition analysis to distinguish the potential shocks, if any. This combination technique could complement the information that the partial adjustment models cannot occur together with the adjustments. Generally, in my article, the model is added a dummy variable to interact with the regressors to detect the effect of these regressors in between the two sub-periods. Then, the variance decomposition analysis of aggregations of the relevant indicators was used to search for the shock that could activate a potential contagion of the interbank capitals.

\section{METHODOLOGIES AND DATA}

To achieve the aim of my article, the procedures have two steps. Firstly, the author uses the partial adjustment models to analyze the adjustment speed of the interbank lending indicator. The estimation is to get the contribution to the adjustment speed of the effective factors. Together with the estimation, the Chaw test with dummy variable is conducted to detect the different effect of the regressors in the pre- and postregulation. The author expects that this technique could give some evidence of differences between these two sub-periods. The evidence from the first step could lead to the analyses to find out whether there are some potential contagion risks from contribution of the relevant factors.

Secondly, the contagion is expected to occur from the relevant shock while the partial adjustment models cannot confirm this. Thus, following the information of the first step, the author uses the variance decomposition analysis to search for the potential shock that might occur from the assets portforlio analysed in the first step. The data for processing are the aggregate average indicators for the procedure of this step. Together with the process, several tests for the assumptions and consistency of the process are conducted.

\subsection{Model}

In a long-run, the interbank lending is a function of the factors that affect itself;

$$
\mathrm{Y}_{\mathrm{i}, \mathrm{t}+1}=\sum_{\mathrm{j}=1}^{\mathrm{j}} \beta_{\mathrm{j}} \mathrm{X}_{\mathrm{j}, \mathrm{i}, \mathrm{t}}+\theta_{\mathrm{n}} \mathrm{C}_{\mathrm{n}, \mathrm{i}, \mathrm{t}}, \mathrm{n}=1,2
$$


Where $\mathrm{Y}$ is the interbank lending of bank $i$, the $X_{j}$ are the vector of factors $j$ th those affect the adjustment of the interbank lending and the $C_{n}$ is control variable that respectively is in the models, $t$ is the quarter point time in the period from 2008/Q1 to 2015/Q4.

The partial adjustment model of the interbank capitals and its target:

$$
\mathrm{Y}_{\mathrm{i}, \mathrm{t}}-\mathrm{Y}_{\mathrm{i}, \mathrm{t}-1}=\lambda\left(\mathrm{Y}_{\mathrm{i}, \mathrm{t}}-\mathrm{Y}_{\mathrm{i}, \mathrm{t}-1}\right)+\varepsilon_{\mathrm{i}, \mathrm{t}}
$$

Where $\lambda$ is the gap or speed of adjustment during a point time, $(0 \leq \lambda \leq 1)$. Substituting equation (1) into equation (2), then a model that the speed of adjustment $(\lambda)$ is estimated as follows:

$$
\mathrm{Y}_{\mathrm{i}, \mathrm{t}}=\sum_{\mathrm{j}=1}^{\mathrm{j}}\left(\lambda \beta_{\mathrm{j}}\right) \mathrm{X}_{\mathrm{j}, \mathrm{i}, \mathrm{t}}+\left(\lambda \theta_{\mathrm{n}}\right) \mathrm{C}_{\mathrm{n}, \mathrm{i}, \mathrm{t}}+(1-\lambda) \mathrm{Y}_{\mathrm{i}, \mathrm{t}-1}+\varepsilon_{\mathrm{i}, \mathrm{t}}
$$

In order to point out the structure break of the $\mathrm{X}_{\mathrm{j}}$ factors in the whole period, the author divides the period into two sub-periods- the pre- and post-regulation periods. The dummy variables $\mathrm{D}_{\mathrm{j}}$ are added to interact with the $\mathrm{X}_{\mathrm{j}}$ vectors. $\mathrm{D}$ received value of 0 for the pre-regulation period and 1 for the post-regulation period. Equation (3) becomes:

$$
Y_{i, t}=\sum_{j=1}^{j}\left(\lambda \beta_{j}\right) X_{j, i, t}+\sum_{j=1}^{j}\left(\lambda \beta_{j}\right) X_{j, i, t} \times D_{j, i, t}+\left(\lambda \theta_{n}\right) C_{n, i, t}+(1-\lambda) Y_{i, t-1}+\varepsilon_{i, t}
$$

The relevance consistency tests of the partial adjustment models fitted are shown in Appendix 1.

In order to search for potential shock, the author uses the variance decomposition analysis in the environment of VAR model. The relevant tests for this procedure are listed in Appendix 2.

\subsection{Variable definitions}

Until the time this article is written, the economic environment of Vietnam has not been a full market economy and is in the process of an integrating with the world economy. The country has set a procedure to apply the Basel regulation framework into the commercial bank sector. Due to such situation, many economic relationships are in the integration process. The free-set interest rate approach has been applied in a couple of years. Foreign exchange rates and the trade of foreign exchange are fully and strictly controlled by the government. Derivatives have been allowed to be traded at the beginning of 2017 . Therefore, in my article, I will exclude the relevant information on derivatives, foreign exchange rates, interest rates and some other related control variables.

In the capital structure studies, the authors frequently added variables in their models those which represent the characteristics of firms or banks as the control variables (Ly et al., 2017; Shimizu, 2015; Cook \& Tang, 2010). In my paper, the natural logarithm of bank's total assets was added as a control variable. This factor is called frequently SIZE and is in my models. Return on assets ratio ROA is the index also used as a control variable in the capital structure analysis. In my paper, the SIZE or ROA attend respectively the models as the control variable for the purpose of a comparison. The comparison could encourage the empirical control variable as in the case of Vietnamese commercial banks.

The interbank lending variable is denoted as IBL. It is a ratio of the interbank lending divided to total assets. The author assumes that the probability of default of the borrowing banks in the interbank capital is zero. This assumption hypothesizes to the alternative analyses of regressors, especially the lending to nonbanks.

The interbank capitals are used to provide the liquidity demand (Vollmer \& Wiese, 2016; Craig et al., 2015; Lucchetta, 2015; Alexius et al., 2014). My study follows these to enhance the systemic risk of the interbank capitals contagion to liquidity risk and to get the point of view regarding the liquidity risk in the analysis. Moreover, instead of borrowing from the interbank market, banks normally mobilize liabilities 
from deposits of individuals as an alternative funding for liquidity demand. So, the author adds into the model a regressor, denoted as DEPO, a ratio of deposits on total liabilities. The association relationship of DEPO with the interbank lending is ambiguous, and this empirical analysis could show a case of the relationship of individual deposits with the interbank lending. Besides, other liabilities denoted as OLIA are important funds for a bank. The evidence from DEPO and OLIA might give evidence of banks' funding for the purpose of their interbank lending target adjustments.

Through network structures, the credit risk is the important one in the interbank system (Langfield et al., 2014), similar to with Langfield et al. (2014) in the analysis of both the interbank lending and the interbank debt. My model includes a regressor for the interbank lending adjustment. This regressor denoted as LOAN, represents a channel of systemic contagion and is calculated by a ratio of total loans on total assets of banks. The author expects that the information from this regressor could help to explain the adjustment of the interbank lending in a negative association.

Cash holding, short term investments and investment to securities are parts of bank's portfolios, which are of a higher liquidity than long-term investments and long-term assets. A regressor added to the model, denoted as HLA, represents high liquidity assets. This ratio could hint a part of the liquidity demand, which relates to the requirement of liquidity standards of the Basel 3. The author expects to have some association relationship behaviors of these assets with the interbank lending of Vietnam throughout the periods.

Following the mechanism of Fink et al. (2016), an indicator calculated by the loan loss allowances was divided by net loans. This indicator denoted as LLA was added to the analysis. According to Fink et al. (2016), an increase in the loan loss allowance leads to a decrease in the interbank lending and it activates a contagion shock. The presence of LLA in the models is expected to show a relevant behaviour of $\mathrm{VcB}$ in the periods.

Table 1

Variable definition

\begin{tabular}{|c|c|c|}
\hline Variable & Definition & Calculation \\
\hline IBL & Interbank lending & $\begin{array}{l}\text { The loans that bank lends to other bank divided by total } \\
\text { assets }\end{array}$ \\
\hline SIZE & Size of the bank's assets & Logarithm of total assets \\
\hline ROA & Return on assets ratio & Net income divided by total assets \\
\hline DEPO & $\begin{array}{l}\text { Deposits from household } \\
\text { ratio }\end{array}$ & $\begin{array}{l}\text { Total deposits from household in bank divided by total } \\
\text { liabilities }\end{array}$ \\
\hline OLIA & Other liabilities ratio & Other liabilities divided by total liabilities \\
\hline LOAN & $\begin{array}{l}\text { Total loan that bank lending } \\
\text { to non-bank ratio }\end{array}$ & $\begin{array}{l}\text { Total loan that bank lends to non-bank customers divided } \\
\text { by total assets }\end{array}$ \\
\hline HLA & High liquidity assets ratio & $\begin{array}{l}\text { Sum of cash holding, short term investment and the } \\
\text { investment to securities divided by total assets }\end{array}$ \\
\hline LLA & Loan loss allowance ratio & Loan loss allowance divided by total net loan to non-bank. \\
\hline
\end{tabular}

\subsection{Data}

Data for the analysis are collected from the quarterly released financial statements of Vietnamese commercial banks which are available in the period from 2008/Q1 to 2015/Q4. In my article, the panel data is used for the adjustment analyses. This technique is similar to the use of data in Shimizu (2015) to analyze the adjustment of denominators capital ratio in Japanese banks, Cook \& Tang (2010) estimated the impact of macroeconomic conditions on the adjustment speed of capital structure, Ly et al. (2017) investigated the effect of Net Stable Funding Ratio adjustment speed on the systemic one. While using the 
variance decomposition analysis, the time series of each factor at the level of the banking industry are aggregated. This is a similar way that Ly et al. (2017) dealt with in their data to calculate the adjustment speed of Net Stable Funding Ratio, and Koch (2014) used to test the cointegration. Following the framework mechanism of Fink et al. (2016) to discuss the empirical evidence from the analyses, the author calculates the overall growth rates of the variables in the models. To distinguish whether the volatility of the effective factors on the adjustment speed are different in the period before and after the regulation launched, the whole period above is divided into two sub-periods, one is the pre-regulation period from 2008/Q1 to 2010/Q4 and the next one is from 2011/Q1 to 2015/Q4, the post-regulation period.

According to the framework developed by Fink et al. (2016), a longer maturity of interbank exposure contributes more to contagion than a short one. Unfortunately, my data set does not have the detailed maturities of the interbank lending. Therefore, this lacks the interbank exposure evidence to highlight an additional contribution to the potential contagion in the interbank lending.

Table 2

Summary statistics

\begin{tabular}{lrrrr}
\hline \multicolumn{1}{c}{ Variable } & \multicolumn{1}{c}{ Mean } & \multicolumn{1}{c}{ Median } & \multicolumn{1}{c}{ Minimum } & \multicolumn{1}{c}{ Maximum } \\
\hline IBL & 0.3030 & 0.2930 & 0.1254 & 0.5669 \\
SIZE & 14.3231 & 14.3574 & 13.2705 & 15.0314 \\
ROA & 0.0019 & 0.0019 & -0.0114 & 0.0167 \\
DEPO & 0.8679 & 0.8994 & 0.5790 & 0.9855 \\
OLIA & 0.0689 & 0.0454 & 0.0007 & 0.4081 \\
LOAN & 0.4504 & 0.4614 & 0.2029 & 0.6517 \\
HLA & 0.1203 & 0.1125 & 0.0264 & 0.2681 \\
LLA & 0.0171 & 0.0140 & 0.0044 & 0.0432 \\
\hline \multicolumn{1}{c}{ Variable } & C.V. & & Ex. Kurtosis \\
\hline IBL & Std. Dev. & 0.3472 & 0.3015 & -0.6779 \\
SIZE & 0.1052 & 0.0265 & -0.6592 & 0.1271 \\
ROA & 0.3790 & 1.0036 & 0.3165 & 24.080 \\
DEPO & 0.0020 & 0.1116 & -0.6547 & -0.6469 \\
OLIA & 0.0968 & 0.9674 & 1.6696 & 3.3739 \\
LOAN & 0.0666 & 0.2372 & -0.2272 & -0.8869 \\
HLA & 0.1068 & 0.4671 & 0.3061 & -0.8130 \\
LLA & 0.0562 & 0.4834 & 0.9590 & 0.2969 \\
\hline
\end{tabular}

Source: Calculated by the author

Growth rate in the period

\begin{tabular}{lllllll}
\hline Indicator & IBL_ave & DEPO_ave & OLIA_ave & LOAN_ave & HLA_ave & LLA_ave \\
\hline Average & $8.44 \%$ & $6.80 \%$ & $38.42 \%$ & $8.08 \%$ & $8.09 \%$ & $\mathbf{1 0 . 7 0 \%}$ \\
\hline Pre-period & $12.02 \%$ & $8.93 \%$ & $55.89 \%$ & $11.27 \%$ & $4.31 \%$ & $\mathbf{1 4 . 0 8 \%}$ \\
\hline Post-period & $4.85 \%$ & $4.67 \%$ & $20.94 \%$ & $4.88 \%$ & $11.87 \%$ & $\mathbf{7 . 3 2} \%$ \\
\hline
\end{tabular}

Source: Calculated by the author 

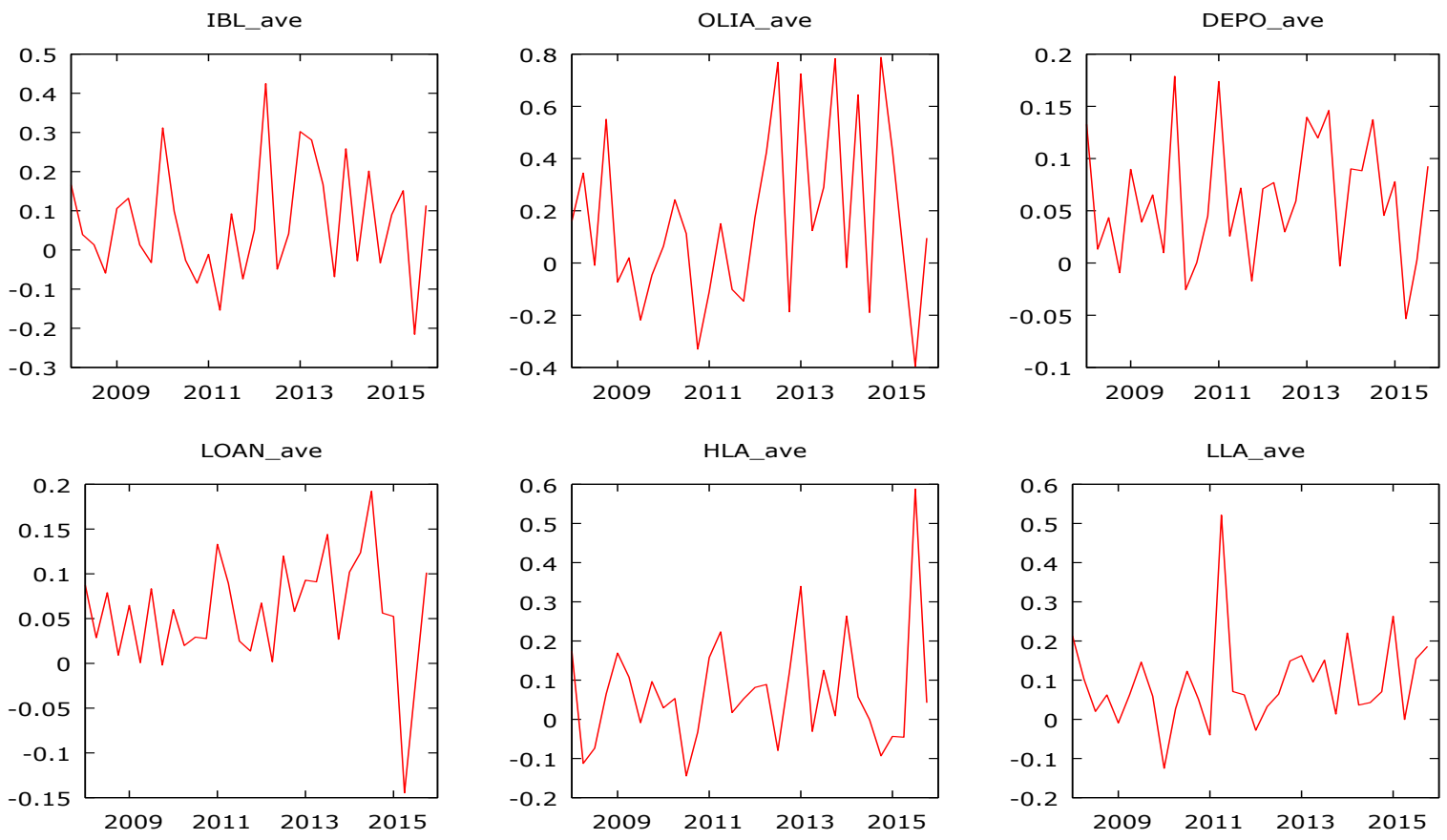

Figure 1. The plot of variables after aggregated into time series

Source: Calculated by the author

\section{EMPIRICAL RESULTS}

My first analysis aims to detect the adjustment speed of the interbank lending. In order to achieve this the regression technique is used. Firstly, a model that computes the panel data is the pooled ordinary least square model. The result from the processing with IBL then tested the consistency. The test shows that the alternative models are fixed effects and random effects, in which the result of the fixed effects model shows a higher speed of adjustment than the one of the random effects model. A part of my intention is to distinguish whether the effective factors have a different effect on the interbank lending in the sub-periods. To do so, together with equation (4), the dummy variables are added to the pooled regression. Therefore, the result from the pooled regression is shown together with the result from the fixed- and random-effects regressions which are estimated by equation (3). The adjustment speeds of the interbank capitals in Tab 4 show that the estimations of fixed-effects models provide a different result experiencing a higher speed than the random-effects models, and, the alternative model diagnostics mostly recommend fixed-effects model is as well. The tests for multicollinearity were also conducted and there is no evidence of any potential from this issue. Secondly, in order to have an overview of the growth in the periods, an average growth rate of the effective factors was calculated and shown in Tab 3. The information confirms that all the indicators increased in the whole period. Before using the VAR model, the variables are tested as shown in Appendix 2. 
Table 4

Regression of partial adjustment models

\begin{tabular}{|c|c|c|c|c|c|c|c|c|}
\hline \multirow[b]{3}{*}{ Coefficient } & \multicolumn{6}{|c|}{ Dependent variable: IBL } & \multirow{2}{*}{\multicolumn{2}{|c|}{ Fix effects }} \\
\hline & \multicolumn{2}{|c|}{ Pooled least square } & \multicolumn{2}{|c|}{ Fix effects } & \multicolumn{2}{|c|}{ Pooled least square } & & \\
\hline & $\begin{array}{l}\text { Short } \\
\text { run } \\
(1)\end{array}$ & $\begin{array}{l}\text { Long } \\
\text { run } \\
(2)\end{array}$ & $\begin{array}{l}\text { Short } \\
\text { run } \\
(3)\end{array}$ & $\begin{array}{l}\text { Long } \\
\text { run } \\
(4)\end{array}$ & $\begin{array}{l}\text { Short } \\
\text { Run } \\
(5)\end{array}$ & $\begin{array}{l}\text { Long } \\
\text { run } \\
(6)\end{array}$ & $\begin{array}{l}\text { Short } \\
\text { run } \\
(7)\end{array}$ & $\begin{array}{l}\text { Long } \\
\text { Run } \\
(8)\end{array}$ \\
\hline \multicolumn{9}{|l|}{ Variable } \\
\hline SIZE & $\begin{array}{r}0.080 * * * \\
{[7.563]}\end{array}$ & 0.100 & $\begin{array}{r}-0.018 \\
{[-1.249]}\end{array}$ & -0.019 & - & - & - & - \\
\hline ROA & - & - & - & - & $\begin{array}{r}5.536 * * * \\
{[3.693]}\end{array}$ & 7.697 & $\begin{array}{r}1.636 \\
{[1.361]}\end{array}$ & 1.784 \\
\hline DEPO & $\begin{array}{r}0.439 * * * \\
{[5.813]}\end{array}$ & 0.549 & $\begin{array}{r}0.049 \\
{[0.858]}\end{array}$ & 0.053 & $\begin{array}{r}0.172 * * \\
{[2.341]}\end{array}$ & 0.240 & $\begin{array}{r}0.048 \\
{[0.845]}\end{array}$ & 0.053 \\
\hline OLIA & $\begin{array}{r}0.071 \\
{[0.842]}\end{array}$ & 0.089 & $\begin{array}{r}-0.019 \\
{[-0.2900]}\end{array}$ & -0.021 & $\begin{array}{r}-0.023 \\
{[-0.2468]}\end{array}$ & -0.031 & $\begin{array}{r}-0.020 \\
{[-0.297]}\end{array}$ & -0.021 \\
\hline LOAN & $\begin{array}{r}-0.667 * * * \\
{[-11.44]}\end{array}$ & -0.833 & $\begin{array}{r}-0.903 * * * \\
{[-21.11]}\end{array}$ & -0.978 & $\begin{array}{r}0.551 * * * \\
{[-9.025]}\end{array}$ & 0.766 & $\begin{array}{r}-0.897 * * * \\
{[-20.86]}\end{array}$ & -0.979 \\
\hline HLA & $\begin{array}{r}-0.189 * * \\
{[-2.145]}\end{array}$ & -0.236 & $\begin{array}{r}-0.601 * * * \\
{[-7.239]}\end{array}$ & -0.651 & $\begin{array}{c}-0.179 * \\
{[-1.847]}\end{array}$ & -0.249 & $\begin{array}{r}-0.557 * * * \\
{[-7.250]}\end{array}$ & -0.607 \\
\hline LLA & $\begin{array}{r}-2.136 * * * \\
{[-3.552]}\end{array}$ & -2.669 & $\begin{array}{r}-0.519 \\
{[-1.143]}\end{array}$ & -0.561 & $\begin{array}{r}0.071 \\
{[0.124]}\end{array}$ & 0.099 & $\begin{array}{r}-0.421 \\
{[-0.9164]}\end{array}$ & -0.459 \\
\hline $\mathrm{IBL}_{\mathrm{t}-1}$ & $\begin{array}{r}0.200^{* * *} * \\
{[4.900]}\end{array}$ & $(0.800)$ & $\begin{array}{l}0.076^{*} \\
{[1.866]}\end{array}$ & $(0.924)$ & $\begin{array}{r}0.281 * * * \\
{[6.569]}\end{array}$ & $(0.719)$ & $\begin{array}{r}0.083 * * \\
{[2.051]}\end{array}$ & $(0.917)$ \\
\hline D_OLIA & $\begin{array}{r}-0.272 \\
{[-3.170]}\end{array}$ & -0.340 & & & $\begin{array}{r}-0.220 \\
{[-2.334]}\end{array}$ & -0.306 & & \\
\hline D_DEPO & $\begin{array}{r}0.160 * * * \\
{[1.371]}\end{array}$ & 0.200 & & & $\begin{array}{r}0.003 * * \\
{[0.026]}\end{array}$ & 0.004 & & \\
\hline D_LOAN & $\begin{array}{r}-0.137 * * \\
{[-2.392]}\end{array}$ & -0.172 & & & $\begin{array}{r}-0.091 \\
{[-1.443]}\end{array}$ & -0.127 & & \\
\hline D_HLA & $-0.305^{* * *}$ & -0.381 & & & $0.244 * *$ & 0.339 & & \\
\hline & {$[-2.820]$} & & & & {$[-1.443]$} & & & \\
\hline D_LLA & $\begin{array}{r}2.094 * * * \\
{[3.039]} \\
\end{array}$ & 2.617 & & & $\begin{array}{r}1.624 * * \\
{[2.158]} \\
\end{array}$ & 2.259 & & \\
\hline R-squared & 0.87 & & 0.85 & & 0.85 & & 0.85 & \\
\hline
\end{tabular}

Bolded numbers in parenthesis ( ) are the values of $\lambda$, numbers in square parenthesis are the values of t-ratio. " $* * *$ ", "***" " $*$ " are the significant at $99 \%, 95 \%, 90 \%$. Source: Calculated by the author

In general, the figures in Tab 4 show that using different control variables gives the approximate results from the models fitted, in which the ROA variable is more statistically significant in the adjustment speed estimation and a little bit less significant in the adjustment speed in comparison with the SIZE variable.

According to the estimation of fixed-effects models shown in Tab 4, the results indicate that in the adjustment of interbank lending is $92.4 \%$, nearly complete in a quarter. This result implies that in short run, interbank lending absorbs mostly the effects for its adjustment. Additionally, in column (3), as expected, the LOAN has a negative association with IBL, and HLA gives an empirical evidence that this indicator has a negative association with IBL. The statistical significances of LOAN and HLA suggest that these assets contribute to the adjustment speed of interbank lending, and these relationships are similar in both the short run and the long run. Moreover, the statistical significances of the dummy variables in column (1), column (5) of Tab 4 and the growth in Tab 3 show that both LOAN, HLA and LLA are significant changes in their effects on the interbank lending between the sub-periods. A higher statistically significant of HLA's coefficient and the invert effect of LLA on IBL mean that HLA strongly changes its contribution to the interbank lending while LLA has a positive relationship with IBL in the post-regulation period. On one hand, these results give evidence characteristics of relationship between LOAN, HLA, LLA and IBL. On 
the other hand, the negative association of LOAN and HLA with IBL imply that the more (or less) banks lend to the interbank capital, the less (or more) liquidity banks get, especially in the post-regulation period, while association of the loan loss allowance with the interbank lending is a latent contagion. Actually, the growth shown in Tab 3 gives good evidence that in the post-regulation period, the growth in high liquidity assets is higher than the growth of the lending. Meanwhile, the growth of LLA is higher than the growth of IBL.

In the long run, a high contribution of LOAN to the adjustment of interbank lending with the negative relationship effect explains that lending in the interbank market or lending to non-banks is a high priority portfolio reallocation in the pre-regulation period and then, the coefficient of LOAN's dummy variable means that lending to non-banks less contributes to the adjustment in the post-regulation period. The author considers connecting the evidence of HLA with the findings of Lee (2013) that when the liquidity of cross banks is imbalanced, the interbank net-work tends to be in a systemic liquidity shortage and the banks become vulnerable to liquidity shocks. However, the growth of these indicators shows that there are some improvements of high liquidity assets in the post-regulation period. But, the variances of this indicator in Tab 5 show that the shock occurs right after the first quarter and stays on the same level in the following quarters.

The results of DEPO in column (3) and column (5) of Tab 4 made me support the findings of Vollmer \& Wiese (2016) about one way effect of the deposits on the interbank lending having a positive association. These results of this indicator also give evidence to support the corollary of Cañón \& Margaretic (2014) that deposits from household could have a positive relationship with the interbank lending.

Table 5

Decomposition of variance for IBL_Ave

\begin{tabular}{crrrrr}
\hline \multicolumn{6}{l}{ Endogenous variables in VAR model: IBL_ave, HLA_ave, LLA_ave, LOAN_ave } \\
\hline period & std. error & IBL_ave & HLA_ave & LLA_ave & LOAN_ave \\
1 & 0.0921931 & 100.0000 & 0.0000 & 0.0000 & 0.0000 \\
2 & 0.118464 & 68.2745 & 27.8800 & 2.7320 & 1.6167 \\
3 & 0.124645 & 64.8666 & 27.0483 & 7.0247 & 1.4911 \\
4 & 0.135795 & 59.4363 & 25.1407 & 10.0553 & 2.0682 \\
5 & 0.169573 & 51.4003 & 31.8786 & 11.6298 & 2.7725 \\
6 & 0.180718 & 47.8846 & 28.0683 & 13.1874 & 2.8183 \\
7 & 0.186408 & 46.6400 & 26.4531 & 16.6924 & 5.2982 \\
8 & 0.216034 & 34.7358 & 21.0511 & 36.5274 & 6.9933 \\
9 & 0.243403 & 28.7233 & 19.5430 & 45.1325 & 6.4956 \\
10 & 0.260975 & 25.3209 & 19.1391 & 47.9744 & 5.7814 \\
\hline
\end{tabular}

Source: Calculated by the author
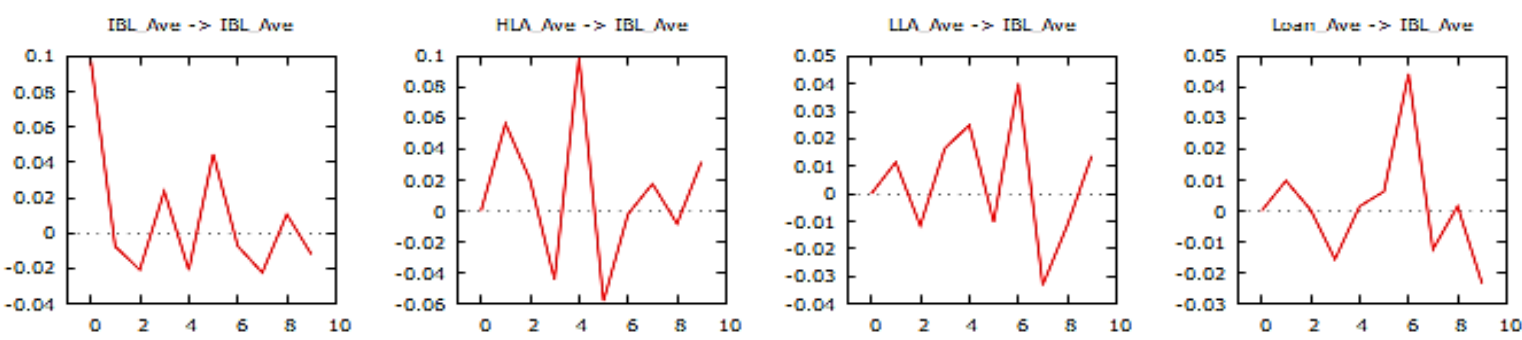

Figure 2. The impulse responses of IBL_Ave

Source: Calculated by the author 
Tab 5 and Fig 2 display the shocks effect on IBL_ave and the impulse of this variable. The forecast shows the potential shock. The HLA-ave_is the soonest and highest shock on IBL_ave in only one quarter lag. After that, from the quarter fourth of lags, LLA_ave indicator is ascending effect on the fluctuation of IBL then become strongest in the quarter tenth of lags.

\section{DISCUSSION}

A higher adjustment speed estimation given by the SIZE variable or the ROA variable when they are respectively control variables could tell that the interbank capital of Vietnamese commercial banks is less sensitive with the ROA. This result is similar to the result of the ROA variable in Ly et al. (2017), in the developed countries, where the ROA is affected by many factors. When comparing the bank efficiency in Austria and the Czech Republic, Svitalkova (2014) argued that the sources of the bank inefficiency in Austria are personnel costs and high broker provisions. In the case of Vietnam, the empirical analysis above showed that a tight control of the SBV on interest rates until 2014 was the main reason why the interbank market did not reflect the real market prices. Thus, the interbank capital of Vietnamese commercial banks was less sensitive with the ROA.

All banks' balance sheets consist of assets and liabilities. Every interbank asset is another bank's liabilities. If a bank has its customer insolvency, this bank still has an obligation to pay to its lender banks in the interbank market. On the one hand, to repay the debt, the borrowers in the interbank market must reduce their assets, use their own liabilities or combine both. On the other hand, when the insolvency of some non-bank lenders increases, the loan loss allowance would increase as well. The liquidity that banks cover for the solvency moves out of a banking system, banks would experience less liquidity. However, in the meantime, some other banks could have surplus liquidity from their mobilizing activities and they could lend such surplus liquidity to other banks which are in need of both their clients' payoff and their own liquidity requirement. In all cases, this activity also makes the potential contagion of interbank capital become more serious. Eisenschmidt \& Tapking (2009) showed that lenders, who face funding problems themselves or who wish to hold precautionary liquidity buffers, may refrain from lending to other financial institutions. In order to implement the regulation requirements, a bank has the loan loss tolerance rate increasing, leading to the lending cutoff in both the interbank market and non-bank borrowers. In addition, according to Jackson et al. (1999), in some periods after the capital regulation, banks in a particular country may find some shortfalls in lending because of the capital regulation requirements which could lead to the lending cutback. This means that in the post-regulation period, the interbank lending may have a reduction. Garcia-de-Andoain et al. (2016) and Craig et al. (2015) believed that the interbank market is a supply channel that provides liquidity for short-run liquidity demand of banks. From these points of view, the empirical evidence could interpret that the change in the interbank market in Vietnam is connected with the system risk. Additionally, the banks with a lower liquidity quality and a higher loan loss tolerance have more vulnerable financial position, and these banks are more likely to be affected by the regulation.

Assuming that the network runs in the same mechanism of the Fink et al. (2016) framework, in which an increase of the loan loss allowance reflects $100 \%$ of the lost event incurred from loans, these effects increase the expected credit losses in the banking sector. As a positive reaction of the capital management, the lending banks have to reallocate their portfolios in the next periods and drive a contagion process which is driven by the interbank lending channel. Tab 5 and Fig 2 display the shocks effect on IBL_ave and the impulse of this variable, in which the LLA_ave indicator has an ascending effect on the fluctuation of IBL from the fourth quarter and becomes strongest in the tenth quarter. In the same situation of the macro and microeconomics, the evidence shows that the contagion from the interbank lending might occur after one 
year from the change in LLA_ave. On the other hand, the change of these assets are depended on the borrowing banks' internal ratting based (IRB), the most used method of Vietnamese commercial bank sector, Blum (2008) and Cipovova \& Belas (2012) also took into account the risks from these mechanisms.

The empirical evidence and forecast above provide a scenario that in the post-regulation period, banks with lower liquidity and hit by the increase in their loans loss allowance are in the earlier potential contagion position, which could cause a reduction in the provision of interbank lending.

Moreover, the loan write-up provision to the total net loans ratio implies the risk of loans' portfolio on the assets of a bank. The higher the risks of loans, the higher the credit risks bank would face, and banks expose themselves to a higher leverage. A further empirical analysis of these relationships could give more evidence of the contagion via the interbank market.

\section{CONCLUSION}

From the interbank lending adjustment analyses of Vietnamese commercial banks in the pre- and postregulation period, the author finds out that the high quality assets is the most contributing factor in the short run. While lending to non-banks contributes with the same level in both short and long run, in the postregulation period; its contribution is lower. In the post-regulation period, the loan loss tolerance has an inverted contribution effect and the highest positive association with the adjustment of the interbank lending. These trend signals are good for the healthy portfolios in the post-regulation period.

The analyses give evidence that to adjust the interbank lending, the process needs a negative association of lending to non-banks and the high liquidity assets; there is evidence that the deposit is positively associated with the adjustment of interbank lending in both pre- and post-regulation periods, while the loan loss allowance has an inverted association. Consequently, assuming that the condition of the post-regulation is stable, the adjustment of interbank lending could face a shock in the decrease of high liquidity assets which occur from the second quarter. Meanwhile, the shock of the loan loss tolerance could occur after a year mostly.

The evidence also points out the fact that it is necessary to add some more disclosure details of the interbank lending portfolios' maturities and straighten monitoring of the IRB of Vietnamese commercial banks as the action to control better the potential risk that might occur from the interbank lending.

\section{ACKNOWLEDGEMENT}

The author is thankful to the Internal Grant Agency of FaME TBU No. IGA/FaME/2017/010: "Financial Constraints on Economic Activities", for financial support to carry out this research.

\section{REFERENCES}

Affinito, M. (2012). Do interbank customer relationships exist? And how did they function in the crisis? Learning from Italy. Journal of Banking \& Finance, 36(12), 3163-3184. https://doi.org/10.1016/j.jbankfin.2011.11.016

Alexius, A., Birenstam, H., \& Eklund, J. (2014). The interbank market risk premium, central bank interventions, and measures of market liquidity. Journal of International Money and Finance, 48, 202-217. https://doi.org/10.1016/j.jimonfin.2014.08.004

Blum, J. M. (2008). Why "Basel II" may need a leverage ratio restriction. Journal of Banking \& Finance, 32(8), 1699_ 1707. https://doi.org/10.1016/j.jbankfin.2007.12.003

Cañón, C., \& Margaretic, P. (2014). Correlated bank runs, interbank markets and reserve requirements. Journal of Banking \& Finance, 49, 515-533. https://doi.org/10.1016/j.jbankfin.2014.03.040 
Cipovova, E., \& Belas, J. (2012). Assessment of Credit Risk Approaches in Relation with Competitiveness Increase of the Banking Sector. Journal of Competitiveness, 4(2), 69-84. https://doi.org/10.7441/joc.2012.02.05

Cook, D. O., \& Tang, T. (2010). Macroeconomic conditions and capital structure adjustment speed. Journal of Corporate Finance, 16(1), 73-87. https://doi.org/10.1016/j.jcorpfin.2009.02.003

Craig, B. R., Fecht, F., \& Tümer-Alkan, G. (2015). The role of interbank relationships and liquidity needs. Journal of Banking \& Finance, 53, 99-111. https://doi.org/10.1016/j.jbankfin.2014.12.022

Distinguin, I., Kouassi, T., \& Tarazi, A. (2013). Interbank deposits and market discipline: Evidence from Central and Eastern Europe. Journal of Comparative Economics, 41(2), 544-560. https://doi.org/10.1016/j.jce.2012.07.005

Distinguin, I., Roulet, C., \& Tarazi, A. (2013). Bank regulatory capital and liquidity: Evidence from US and European publicly traded banks. Journal of Banking \& Finance, 37(9), 3295-3317. https://doi.org/10.1016/j.jbankfin.2013.04.027

Eisenschmidt, J., \& Tapking, J. (2009). Liquidity risk premia in unsecured interbank money markets. Retrieved from https://papers.ssrn.com/sol3/papers.cfm?abstract id=1340854

Fink, K., Krüger, U., Meller, B., \& Wong, L.-H. (2016). The credit quality channel: Modeling contagion in the interbank market. Journal of Financial Stability, 25, 83-97. https://doi.org/10.1016/j.jfs.2016.06.002

Garcia-de-Andoain, C., Heider, F., Hoerova, M., \& Manganelli, S. (2016). Lending-of-last-resort is as lending-of-lastresort does: Central bank liquidity provision and interbank market functioning in the euro area. Journal of Financial Intermediation. https://doi.org/10.1016/j.jfi.2016.01.003

Georg, C.-P. (2013). The effect of the interbank network structure on contagion and common shocks. Journal of Banking \& Finance, 37(7), 2216-2228. https://doi.org/10.1016/j.jbankfin.2013.02.032

Heider, F., Hoerova, M., \& Holthausen, C. (2015). Liquidity hoarding and interbank market rates: The role of counterparty risk. Journal of Financial Economics, 118(2), 336-354. https://doi.org/10.1016/i.jfineco.2015.07.002

in 't Veld, D., \& van Lelyveld, I. (2014). Finding the core: Network structure in interbank markets. Journal of Banking \& Finance, 49, 27-40. https://doi.org/10.1016/i.jbankfin.2014.08.006

Jackson, P., Furfine, C., Groeneveld, H., Hancock, D., Jones, D., Perraudin, W., ... Yoneyama, M. (1999). Capital requirements and bank behaviour: the impact of the Basle Accord. Bank for International Settlements Basel. Retrieved from http://www.bdresearch.org/home/attachments/article/485/bcbs_capital\%20requirement $\% 20$ and $\% 20$ effect.pdf

Koch, C. T. (2014). Risky adjustments or adjustments to risks: Decomposing bank leverage. Journal of Banking \& Finance, $45,242-254$.

Langfield, S., Liu, Z., \& Ota, T. (2014). Mapping the UK interbank system. Journal of Banking \& Finance, 45, $288-303$. https://doi.org/10.1016/j.jbankfin.2014.03.031

Lee, S. H. (2013). Systemic liquidity shortages and interbank network structures. Journal of Financial Stability, 9(1), 1-12. https://doi.org/10.1016/i.jfs.2012.12.001

Lucchetta, M. (2015). Does the bank risk concentration freeze the interbank system? The North American Journal of Economics and Finance, 33, 149-166. https://doi.org/10.1016/j.najef.2015.04.002

Ly, K. C., Chen, Z., Wang, S., \& Jiang, Y. (2017). The Basel III net stable funding ratio adjustment speed and systemic risk. Research in International Business and Finance, 39, 169-182. https://doi.org/10.1016/j.ribaf.2016.07.031

Mendel University in Brno, \& Svitalkova, Z. (2014). Comparison and Evaluation of Bank Efficiency in Austria and the Czech Republic. Journal of Competitiveness, 6(2), 15-29. https://doi.org/10.7441/joc.2014.02.02

Shimizu, K. (2015). Adjusting denominators of capital ratios: Evidence from Japanese banks. Journal of Financial Stability, 19, 60-68. https://doi.org/10.1016/j.jfs.2015.05.005

Temizsoy, A., Iori, G., \& Montes-Rojas, G. (2015). The role of bank relationships in the interbank market. Journal of Economic Dynamics and Control, 59, 118-141. https://doi.org/10.1016/j.jedc.2015.07.008

Tian, S., Yang, Y., \& Zhang, G. (2013). Bank capital, interbank contagion, and bailout policy. Journal of Banking \& Finance, 37(8), 2765-2778. https://doi.org/10.1016/j.jbankfin.2013.03.024

Vollmer, U., \& Wiese, H. (2016). Central bank standing facilities, counterparty risk, and OTC-interbank lending. The North American Journal of Economics and Finance, 36, 101-122. https://doi.org/10.1016/i.najef.2015.12.003

The State Bank Of Vietnam. (2010). Providing for the prudential ratios in activities of credit institutions. No. 13/2010/TT-NHNN, dated May 20th 2010, Circular. 